\title{
Hoybun Örgütü: Kürt Milliyetçiliğinde Yeni Bir Evre
}

Hoybun Organization: A new era in Kurdish Nationalism

\author{
Selin M. Bölme ${ }^{1}$
}

\begin{abstract}
This article aims to analyze the role, structure and activities of the Xoybun Organization in taking the Kurdish issue out to the international platforms. Despite the fact that organization did not achieve major gains during its lifetime, it provided a fresh breath and a great deal of experience to the Kurdish movements afterwards. Contrary to the Kurdish organizations that were set up before it, Xoybun Organization was structured around a military and administrative configuration. Further, believing that establishment of an independent Kurdistan depended on international support, they concentrated their efforts on international lobbying, and attempted to receive attention of the international community with various publications on the Kurdish issue. In doing so, they ushered a new era in Kurdish nationalism.
\end{abstract}

Keywords: Xoybun, Ağrı Uprising, Kurdish Nationalism, Kurdish Problem, Turkey

\section{Özet}

$\mathrm{Bu}$ çalışmada Kürt sorununun uluslararası alana taşınmasında öncü olan Hoybun Örgütü’nün kuruluş süreci, bu süreci etkileyen faktörler, yapısı ve faaliyetleri ve dağılma süreci incelenmiştir. Örgüt, kendi döneminde çok ciddi kazanımlar elde edemese de, pek çok yönü ve yaklaşımları ile Kürt hareketine yeni bir soluk getirmiştir ve kendinden sonraki dönem için önemli bir birikim bırakmıştır. Hoybun'dan önceki örgütlenmelere baktığımızda, bu şekilde askeri ve idari yapılanma içine giren bir örgüt olmadığını görürüz. Daha önemlisi Hoybun, bağımsız bir Kürt devletinin kurulabilmesi sorunu uluslararası alana taşımanın gerekliliğine inanarak yabancı devletlerden destek arayışına girmiş, yayınları ile uluslararası kamuoyunun dikkatini çekmeye çalışmıştır. Bu yönüyle Kürt milliyetçiliğinde yeni bir evre başlatmıştır.

Anahtar kelimeler: Hoybun, Ağrı Ayaklanması, Kürt Milliyetçiliği, Kürt Sorunu, Türkiye

Recommended citation:

Bolme, S. M. (2015). Hoybun Örgütü: Kürt milliyetçiliğinde yeni bir evre [Hoybun Organization: A new era in Kurdish Nationalism] International Journal of Kurdish Studies 1 (2), pp.35 - 55.

\footnotetext{
${ }^{1}$ Yrd.Doç.Dr., Marmara Üniversitesi, Ortadoğu ve İslam Ülkeleri Araştırmaları Enstitüsü

E-mail: selin.bolme@marmara.edu.tr
} 


\section{GİIȘ}

Toplumsal olarak aşiretler şeklinde örgütlenmiş olan Kürtler arasında milliyetçi fikirlerin doğuşunu 19. yüzyılın başlarına kadar götürebilmek mümkündür. Bununla birlikte ilk siyasi örgütlenmeler, 1908'de Meşrutiyetin ilan edilmesinin ardından doğan özgürlükçü ortamda, milliyetçi fikirlerin güçlenmesi ile başlamıştır. Bu dönemde kurulan örgütler Kürt milliyetçiliğinin gelişmesinde önemli roller üstlenmişlerdir. Kurtuluş Savaşı'nın sona ermesi ve Türkiye Cumhuriyeti'nin kurulması Kürt hareketi için de dönüm noktası olmuştur. Yeni kurulan ulus devleti muhafaza etmek isteyen Cumhuriyet idaresi ile Anadolu'nun doğusunda Kürt devleti kurmak isteyen Kürt liderler arasında bir çatışma dönemi başlamıştır. Bu çatışmanın başlaması ile Kürt örgütlenmeleri illegal ilan edilmiş; bunun üzerine Kürtler gizli olarak örgütlenmeye yönelmiş ve bu şekilde propoganda, basın-yayın faaliyetlerini yürütmüşlerdir.

1925 yılında başlayan Şeyh Said İsyanı, aynı günlerde çıkarılan Takriri Sükun Yasası ve Diyarbakır ve Ankara'da kurulan İstiklal Mahkemeleri ile birlikte Türkiye Cumhuriyeti'nin Kürtlere karşı sertleşen politikası yeni bir evreye girmiştir. 1927'de çıkarılan kanunla Kürtlerin yaşadığı bölgelerin büyük kısmını kapsayacak şekilde Genel Müfettişlik kurulmuş ve aynı tarihlerde 'Bazı Eşhasın Şark Menatıkından Garp Vilayetlerine Nakillerine Dair Kanun' nun çıkarılması ile sakıncalı görülen kişi, grup ve aşiretlerin zorla Batı illerine göç ettirilmesi süreci başlamıştır (Göktaş 1991: 54-55). Bu ortamda, kaçabilen Kürt aydınlar, asker ve subaylar, İran, Irak ve Suriye'ye sığınmışlar ve çok geçmeden yeni şartlar altında örgütlenme fikirlerini tartışmaya başlamışlardır (Kalman 1997: 33, Karaca 2003: 19). Bu tartışmalardan, Kürt milliyetçiliğine farklı bir soluk getirecek Hoybun Örgütü doğmuştur. Hoybun, hem oluşturduğu askeri ve idari yapılanma ile hem de bağımsız bir Kürt devleti fikrini dünya kamuoyuna duyurma çabaları ile Kürt hareketini yeni bir evreye taşımıştır.

\section{Hoybun'un Kuruluşu}

Kürt hareketinde Şeyh Said isyanı ardından yeniden bir birlik kurma yönünde çabalar 1926-1927 yılları arasında yoğunluk kazanmıştır. Hareketin önderliğini İskender takma adı ${ }^{2}$ ile bilinen 1922'de İstanbul'u terkederek Suriye'ye gelen Memduh Selim yapmıştır. (Kurubaş 1997: 173, Ekrem Cemil Paşa 1991: 67) Bu dönemde Belçika'da toplanan 'Baskı Altındaki Milletler Konferansı'na yazılar göndererek Kürtlere yapılan uygulamaları anlatan ve Avrupa'nın dikkatini çekmeye çalışan Memduh Selim, Şeyh Sait İsyanı'ndan sonra bölgeye gelen Kürtlerle yeni bir örgütlenme için temaslara başlamıştır. Görüştüğü kişiler arasında Dr. Mehmet Şükrü [Sekban], İhsan Nuri, Şeyh Said'in oğlu Ali Rıza, Berazi aşireti reisi Mustafa Şahin, Paris'te bulunan Şerif Paşa ve Mısır'da bulunan Celadet ve Kamuran Bedirhan yer almaktadır. Toplantılar neticesinde bir Kürt kongresi toplanması konusunda görüş birliğine varılmış ve bu amaçla birçok aşiret reisinin de desteği sağlanmıştır (Alakom 1998: 22; Kurubaş 1997: 172; Göktaş 1991: 93; Kahraman 2004: 213).

\footnotetext{
2 Alakom’a göre “Bazı kaynaklarda Memduh Selim ile İskender ayrı iki şahsiyetmiş gibi yanlış bir takım saptamalar yer almaktadır.” (Alakom 1998: s.22)
} 
Araştırmacılar arasında Hoybun'un ilk toplantısının ne zaman, nerede yapıldığı ve örgütün nasıl kurulduğu konusunda fikir ayrılıkları bulunmaktadır. Bazı yazarlar (Alakom 1998, Göktaş 1991), 'Kürt Ulusal Kongresi' olarak adlandırılan ilk kuruluş toplantısının 5 Ekim 1927'de Lübnan'ın Bihamdun kentinde, Ermeni Taşnak Örgütü'nün merkez komite üyesi Vahan Papazyan'1n evinde gerçekleştiğini belirtmektedirler. Kalafat'a (1992: 134) göre ise, ilk toplantı Şubat 1927'de Revanduz'daki [Irak] Seyit Taha'nın evinde İngilizlerin ve Ermenilerin yardımı ile yapılmıştır. Hakkı Öznur (2003: 271) Revanduz'daki ilk toplantı konusunda Kalafat'a katılmakla birlikte, kuruluştan sonra ilk kongrenin 5 Ekim 1927'de Bihamdun'da yapıldığını söylemektedir. Diğer bazı yazarlar ise (Yıldız 1992: 218, Kurubaş 1997: 173, Şadillili 1980: 176) Hoybun'un ilk toplantısını 1927 senesinde Bağdat'ta Emirizyan'ın Londra Oteli'nde gerçekleştirdiğini ileri sürmektedirler. Alakom'a göre (1998: 24) ilk toplantının Irak'ta yapıldığını söyleyen kaynaklar büyük bir olasılıkla Hoybun'un siyasetini benimsemeyen bazı Kürtlerin Irak'ta kurduğu 'Teali Örgütü'nün kuruluşu ile Hoybun'un kuruluşunu birbirine karıştırmaktadır. Bir takım kaynaklara göre ise (Alakom 1998: 24'ten Gürsel 1977: 53) Hoybun 1920 senesinde Paris'te kurulmuştur. Burkay ise (1978) Hoybun'un Kürt Teali Cemiyeti, Kürt Teşkilat-ı İçtimaiye Cemiyeti, Kürt Milli (Millet) Fırkası ve Kürt Bă̆ımsızlık Komitesi adlı dört örgütün birleşmesinden oluştuğunu ileri sürmektedir. Bir birleşmeden söz edilmese de, toplantıya bu örgütlerin temsilcilerinin katıldıkları başka kaynaklarda da dile getirilmektedir (Aytepe 1998b:50, Alakom 1998:22).

İlk toplantıya ilişkin farklı tarih ve yerler ifade edilmekle birlikte, Kürt Ulusal Kongresi tarafından yayınlanan 1928 tarihli "Nizamname-i Umumi ve Peyam-1 Milli" adlı tüzüğün 1. maddesinde "Maksat, 1927 senesi teşrinievvelinin [Ekim] beşinci günü ikat eden birinci Kürt Kongresi'nin kararlyla ve Hoybun namile milli bir Kürt Cemiyeti teşekkül eylemiştir" ifadesi yer almaktadır (Karaca 2003: 20'den Hoybun Nizamnamesi). Kongre hayata geçirilene kadar Kürtlerin sığındıkları Irak, Suriye, İran ve Paris'te örgütlenme fikri ile çeşitli toplantılar gerçekleştirmiş olmaları ihtimali, kuruluş yeri ve tarihi konusunda karışıklığ açıklamaktadır. Nitekim benzer bir kanaatle Kurubaş da kitabında (1997: 174) Irak’ta gerçekleştiği söylenen toplantıların kuruluş öncesi hazırlık toplantıları olduğunu belirtmektedir. Bu nedenle kuruluşu 5 Ekim 1927'de Bihamdun'daki kongre olarak almak doğru olacaktır.

Benzer bir görüş ayrılığı 'hoybun'un kelime anlamı konusunda da vardır. Bazı kaynaklarda (Kalafat 1992: 136) 'benlik', 'özbenlik'; bazılarında (Jwaideh 2003: 409, Karaca 2003: 19) 'bağımsızlık' olarak geçmektedir. Kimi yazarlar, örgütteki Ermeni etkinliğine de vurgu yaparak; 'hoybun'un Kürtçe 'benlik' ve 'haybun'un ise Ermenice 'vatan' anlamına geldiğini ve 'hoybun' kelimesinin bu kelimelerin birleştirilmesinden ortaya çıktığını ileri sürmektedirler. Bu konuda detaylı etimolojik bilgi veren Alakom (1998: 17-18) kelimenin Kürtçe'deki yazılışından yola çıkarak, xo (kendi) ve bûn (olmak) kelimelerinin birleşmesinden 'xobun' olacağını, Kürtçe'de bağımsızlık için 'serxwebûn' 'serbexoyi' sözcüklerinin kullanıldığını, 'hoybun’ kelimesinin, Kürtçe'nin sözcük hazinesi bakımından ölü bir sözcük olduğunu; ayrıca Ermenice'de 'hay'ın 'vatan' anlamına geldiğini, dolayısı ile 'hoybun'un ileri sürülen anlamların hiçbirine gelmediğini yazmaktadır. Kürtçe sözlüklerde de 'xoybun' kelimesi yer almamaktadır. 'Xo'nun Zaza lehçesinde karş1lığı 'kendi' iken Kurmanci'de bir karşılı̆ğ yoktur. 'Bûn' kelimesi ise Kurmanci'de 'başlamak', 'olma', 
'oluşma,' anlamlarına gelmektedir, ancak Zazaca bir anlamı yoktur (Ferheng Online Sözlük). İki lehçenin birleşmesi ile bir sözcük yaratılmış olması çok zayıf bir ihtimaldir. Dolayısıyla Alakom'un "Kürtçe açısından ölü bir sözcük" tanımlaması en akla yatkın açıklamadır. 'Xoybûn' bir kısaltmadan veya Ermenci bir kelime ile birleşmeden doğmuş olabilir. Örgütün kendi yayınlarında ise bu konuda bir açıklama yapılmamıştır.

I. Üyeler ve Örgüt İçi Rolleri: Bedirhanlar'dan Cemilpaşazadeler'e

Hoybun kelimesinin kökeni ve örgüt'ün nerede ne zaman kurulduğu yönünde farklı fikir ve görüşler ileri sürüldüğü gibi örgüte üye olanlar, ne zaman örgüte girdikleri, kimlerin hangi görevleri üstlendiği konusunda da farklı ifadeler söz konusudur. Daha önce de belirtildiği gibi hareketin başını Memduh Selim çekmektedir. Memduh Selim, Türkiye, Mısır, Suriye, Irak, Avrupa ve Amerika'da bulunan Kürtlerden oluşan kalabalık bir kitle ile temaslar kurarak 'Kürt Kongre'sini hayata geçirmiştir (Kurubaş 1997: 172). Daha sonra aftan yararlanarak Türkiye'ye dönüp Antakya Lisesi'nde öğretmenliğe başlayan Memduh Selim'in burada da Hoybun'un bir şubesini kurduğu söylenmektedir (Alakom 1998: 41) Memduh Selim, örgütün kuruluşundan dağılışına kadar örgüt içinde kalmış bir kaç kişiden biridir.

Örgütün kuruluş aşamasında ilk toplantısının Revanduz'da gerçekleştirildiğini yazan Kalafat (1992: 134), bu toplantıya Seyit Taha, kardeşi Mustahattin, Balık aşireti reisi Mehmet Ağa, Şeyh Sait'in akrabalarından Hınıslı Mehmet Emin, Menkuri aşireti reisi Seivar Ağa ve İngiliz elçiliğinden Kaptan Moltfortre ile katibinin katıldığını belirtmektedir. İlk toplantının Bağdat'ta Londra Otelinde olduğunu söyleyen Şadillili'ye (1980: 166) göre bu toplantiya Ermeniler adına Levon, Emirizyan, Sultanyan ve Ariş adlı önderler ile Kürtlerden Ali Rıza, Dr. Şükrü Mehmet (Sekban), Mehmet Emin (Broşki), İhsan Nuri, Hurşit ve Abdülkerim Fehmi katılmıştır.

Sayılan bu isimlerin kuruluş aşamasında çeşitli toplantılarda yer almış olmaları muhtemeldir. 1927 senesinde gerçekleşen Kongre'ye katılan isimler üzerinde biraz daha netlik olduğunu söylemek mümkündür. Kongre Dr. Mehmet Şükrü başkanlığında çalışmalara başlamış ve Memduh Selim, Celadet ve Kamuran Ali Bedirhan, Şahinzade Mustafa, Malatya Mutasarrıfı Halit Fehmi, Liceli Fehmi, Şeyh Sait'in kardeşi Mehdi, Süleymaniyeli Abdülkerim, Şeyh Said'in oğlu Ali Rıza'ya vekaleten Haco Ağa, Ramanlı Emin ve kaçak Osmanlı zabiti Hurşit ile birlikte Ermenilerden Taşnak önderi Vahan Papazyan burada hazır bulunmuştur (Şadillili 1980: 166).

Özellikle Şeyh Sait'in oğlu Ali Rıza'nın örgütte hangi toplantılara katıldığı ve hangi şekilde ayrıldığı konusunda birbirinden farklı görüşler mevcuttur. Kalafat (1992: 134), Revanduz'da gerçekleşen Hoybun'un üçüncü toplantısında bir takım anlaşmazlıklar çıktığını, bu anlaşmazlıklar neticesinde Seyit Taha örgütten ayrılırken, Ali Rıza'nın bundan sonra ilişkilerinin zayıfladığını ileri sürmektedir. 1931 tarihinde Milli Emniyet (MİT) tarafından yayınlanan bir broşürde, Beyrut'ta yapılan kongrede başkanlığa Ermenilerden Papazyan'ın seçilmesi üzerine, başkanın bir Kürt olmasını isteyen Ali Rıza ve adamlarının buna itiraz ettiklerini aktarılmaktadır. Buna göre; tartışmalar sonucu Ermeniler ve Bedirhanlar, Ali Rıza ve taraftarlarının örgütten çıkarılmasını istemişler ve Ali Rıza ve adamları ayrılarak başka örgüt kurmuşlardır (Kaya: 2001, Sarınay 1998:6). Ali Rıza'nın oğlu M. Fuat Fırat, bir röportajında İngilizlerin babasının Hoybun Kongresi'ne katılmasına izin vermediklerini ve 
babasının kendi vekâletini amcası Şeyh Mehdi ve Liceli Fehmi’ye verdiğini, bu iki kişiyi kendi yerine gönderdiğini ileri sürmüştür (Alakom 1998: 32). Bununla birlikte, Hoybun'un ilk kuruluş toplantısına katılan Ahmed Abdurrahman Ağa anılarında Hoybun'un merkez komitesinin listesini vermektedir ve burada Ali Rıza'nın da adı yer almaktadır. Diğer isimler ise şunlardır: Celadet Bedirhan, Memduh Selim, Dr. Mehmet Şükrü (Sekban), Haco Ağa, Ramanlı Emin, Mustafa Şahin, Bozan Şahin, Kerim Bey, Tefik Bey, Kamil Bey, Bedrettin Ağa, Liceli Fehmi (Alakom 1998: 30). Bu bilgilerden hareketle, Ali Rıza'nın örgütün kuruluş aşamalarında yer aldığını, Kongre'ye muhtemelen katılamadığını ancak kısa bir süre örgütte yer aldıktan sonra, çıkan anlaşmazlık sonucu ayrıldığını söylemek mümkündür.

Hoybun örgütü ile beraber adı en çok anılan bir diğer isim ise Celadet Bedirhan'dır. Celadet Bedirhan örgütün kuruluş aşamasından itibaren önemli bir konuma sahiptir. Bunun yanı sıra kardeşleri Kamuran ve Süreyya Bedirhan da örgüt faaliyetlerinde aktif rol almışlardır. Kimi kaynaklara göre, örgütün başkanlığına Vahan Papazyan seçilirken, Genel Sekreterliğine Celadet Bedirhan getirilir (Kalafat 1992: 137, Şadillili 1980: 168-169). Ancak pek çok kaynakta, Celadet Bedirhan'ın ismi Hoybun'un ilk başkanı olarak geçmektedir. ${ }^{3}$ Hoybun Örgütü'nün kuruluşu ve faaliyetleri hakkında Dahiliye Vekaleti'nin 19 Ağustos1929 tarihli raporu da bunu doğrulamaktadır (BCA 030.10.115/803/5). 1927'de Türkiye Hükümeti'nin ilan ettiği genel af sonrasında, Suriye ve Irak'a geçmiş olan pek çok şeyh, ağa ve beyin geri dönmesi sonrasında örgütün kontrolü tümüyle Bedirhanlar'a geçmiştir (Cegerxwin 2003: 190). Buna göre; Celadet Bedirhan 1927-1932 y1lları arasında örgüt içinde aktif olarak çalışmıştır. Süreyya Bedirhan ise örgütün özellikle dış ilişkilerinde önemli roller üstlenmiş, Mevlanazade Rıfat ile birlikte Ermeniler'le yakın ilişkiler kurmuştur. ABD'deki Kürtleri örgütlemek ve ABD yönetimi ile halkına Kürtler hakkında bilgi vermek üzere Hoybun adına çeşitli kereler ABD’ye gitmiştir (Bedirhan 1994: 9). Bedirhan kardeşler, özellikle Hoybun'un propaganda faaliyetlerine büyük önem vermişler ve bu konuda pek çok yayını kendileri kaleme almışlardır. Şam, Beyrut ve Paris’te şubeler kuran Celadet, Kamuran ve Süreyya Bedirhan beyler, bir nevi diplomatlık görevi üstlenmişler ve uluslararas1 kamuoyunun dikkatini Kürt isteklerine çekmek için gayret göstermişlerdir (Alakom 1998: 40). Hareket içinde çıkan anlaşmazlıklar sonucu 1932 yılında Kamuran Bedirhan'ın örgütten çıkarılması üzerine, Celadet Bedirhan da örgütten ayrılmış ancak Hoybun'la ilişkileri bundan sonra da devam etmiştir (Malmisanij 2004:224).

Hoybun'un kurucuları arasında yer alan diğer bir isim ise Dr. Mehmet Şükrü Sekban'dır. Mehmet Şükrü'nün ismine Hoybun'dan önce kurulan önemli Kürt örgütlerinde kurucu sıfatı ile rastlamak mümkündür. Bazı kaynaklara göre Mehmet Şükrü, 1927'den itibaren Hoybun'un Bağdat Şubesi Başkanlığını yürütmüştür. $\mathrm{Bu}$ dönemde Milletler Cemiyeti'ne Kürt sorunu ile ilgili mektup göndererek, sorunu uluslararası platforma taşımaya çalışmıştır (Kurubaş 1997: 185, dn.164). Hoybun'dan ne zaman ayrıldığı tam olarak bilinmemektedir. Ancak af ile Türkiye'ye dönmesi ve 1933 yılında Fransa'da yayınlanan 'Kürt Sorunu' adlı kitabında Türk Hükümeti'nin tezlerini destekleyen görüşlere yer vermesi

\footnotetext{
3 Alakom (1998: 36-37), Bazil Nikitin, E.G.Elpinston, Erhart Franz ve Nazmi Sevgen gibi pek çok araştırmacının Hoybun'un ilk başkanı olarak Celadet Bedirhan'ı gösterdiklerini yazar. Ayrıca Jwaideh (2003: 409) Hoybun'un ilk başkanı olarak Celadet Bedirhan'ın ismini verir.
} 
üzerine, Kürt milliyetçileri arasında saygınlığını yitirdiği bilinmektedir (Kurubaş 1997: 186; Alakom 1998: 42). Muhtemelen aynı dönemde Hoybun'la olan bağları da kopmuştur.

Ağrı İsyanı'nın komutanı olarak ön plana çıkan İhsan Nuri, Hoybun'un en bilinen isimlerden biridir. İstanbul'da Harp Akademisi'nde eğitim görmüş ve ardından Osmanlı Ordusu'nda görev almıştır. Çeşitli Kürt örgütlerinde İhsan Nuri’nin adını görmek mümkündür. Azadi üyesiyken başlattıkları ayaklanma sonrasında Irak'a kaçmış ve burada Hoybun'un kuruluş çalışmalarından haberdar olmuştur (Kalman 1997: 53). İhsan Nuri, Hoybun'un ilk merkez komitesinde yer almış (Alakom 1998: 33) sonrakilere de Ağrı delegesi sıfatı ile katılmıştır (Bayrak 1994: 89). İhsan Nuri'nin Hoybun açısından esas önemi, kendisinin Ağrı İsyanı'nı örgütlemek ve yönetmek üzere örgüt tarafindan "Başkomutan” sıfatı ile atanmış olmasıdır (İhsan Nuri Paşa 1992: 7). İsyan bastırıldıktan sonra, İran'a kaçan İhsan Nuri'nin bu noktadan sonra örgütle ilişkileri kesilmiştir (Alakom 1998: 79).

Hoybun'un kurucuları arasında yer almamakla birlikte, özellikle Bedirhanlar örgütten ayrıldıktan sonra, yönetimde ön plana çıkan isimler Cemilpaşazadeler'dir. Cemilpaşazade Ekrem, Misır'da bulunan Celadet ve Kamuran Bedirhan Beyler'in ve Memduh Selim'in daha Bihemdun Kongresi'nden önce birçok defalar yazdıkları mektuplardaki rica ve israrların neticesinde Hoybun'a katıldıklarını söylemektedir (Ekrem Cemil Paşa 1989: 72). Ali Rıza ve arkadaşlarının Türkiye'ye döndükleri bu dönemde Hoybun bir dağılma içine girmiştir. Cemilpaşazadeler'den Kadri, Ekrem, Bedri, Mehmet (Muhammed) 1929'da Mikdat (Mikdad) ise bir yıl sonra Suriye'ye geçmişlerdir (Ekrem Cemil Paşa 1989: 67). Bu süreçte Doktor Ahmet Nafız Bey, Şevket Bey, Osman Sabri Bey, Reşit Kurd ve Kadri Can da örgüte katılmış ve Hoybun'u yeniden canlandırmak için çalışmaya başlamışlardır (Cegerxwin 2003: 207). Cemilpaşazade Ekrem (1989: 77), 1934-1939 arasında Cemilpaşazade Kadri’nin, 1939-1946 yılları arasında ise kendisinin Hoybun'un siyasi temsilciliğini yaptığını belirtmektedir.

\section{Amaçlar : Türkiye'deki Kürtler için Birlik ve Bă̆ımsızlık}

Hoybun'un nihai amacı hiç şüphesiz Kürtler için bağımsızlıktır. Bu bağımsızlık hedefi, 1928 y1lında "Nizamname-i Umumi ve Peyman-1 Milli” adı ile Hoybun'un tüzüğünde ${ }^{4}$ Örgütün amact Türkiye boyunduruğu altında bulunan Kürdistan ve Kürtlerin kurtuluşu ve doğal ve ulusal sınırlart içinde bă̆ımsız bir Kürdistan devleti kurmak sözleri ile ifade edilmiştir. Burada da görüldüğü gibi hedef bütün Kürtlerin bağımsızlığı değildir; örgüt amacını Türkiye sınırlarında yaşayan Kürtlerlerin kurtuluşu ile sınırlandırmıştır. Bu bağımsızlık hedefine ulaşabilmek için Türkiye'deki Kürtler arasında birliğin sağlanması öncelikli hedef görülmüştür. Nitekim Kongre sonunda Kürtler arasındaki aşiret kavgalarının kan davalarının, kurulan birliğe zarar vermemesi için, örgüte üye olan kişilerin "Kardeşlik Andı"nı içmesine karar verilmiştir. Bu anda göre; iki yıl süresince kan davaları ertelenecek, anlaşmazlıklar unutulacak ve Kürtler birbirlerine silah çekmeyeceklerdir. Ayrıca tek bir çatı altında toplanabilmek adına daha önce kurulan örgütlerin feshi de karara bağlanmıştır (Bayrak 1994: 87).

\footnotetext{
4 "Tüzüğün elde bulunan nüshasının son iki sayfası okunamadığı için, belgenin tam olarak kaç maddeden oluştuğu bilinmemektedir." (Alakom 1998: 25)
} 
Türkiye sınırları içindeki Kürtler için birlik ve bağımsızlık hedefi konulduktan sonra tüzükte bunu gerçekleştirmek için iki yöntem belirlenmiştir: askeri mücadele ve propaganda. ${ }^{5}$ Uluslararası destek sağlama konusu Hoybun'un başından itibaren titizlikle üzerinde durduğu konulardan biri olmuştur. Nitekim bu desteğe duyulan ihtiyaç bağımsızlığın Türkiye Kürtleri ile sınırlandırılmasındaki önemli gerekçelerden biridir. Hoybun'un ilk Kurultay'ında Suriye ve Mezopotamya Kürtlerine manda koşullarıla yetinmek ve onlar için hiç bir politik hak talebinde bulunmayıp bu hükümetlerle iyi ilişkiler kurmak kararı alınmıştır (Bayrak 1994: 87). $\mathrm{Bu}$, doğrudan doğruya Suriye ve Irak'taki Kürtlerin bağımsızlık taleplerini desteklemediklerinin ilanıdır. Örgüt, Batı'nın desteğine duyduğu ihtiyaçtan ötürü daha geniş çaplı bir kurtuluş hedefi ile İngiltere ve Fransa'yı karşısına almak istememiştir. Ayrıca örgütün ileri gelenlerin sığındıkları ve faaliyetleri yürüttükleri ülkelerin Irak ve Suriye olduğu gözönüne alınırsa bu örgütün varlığını sürdürebilmesi açısından da bu bir zorunluluktur. Sonuç bildirgesinde sadece, Irak içinde bir Kürt özerkliği konusunda Milletler Cemiyeti tarafindan ileri sürülen isteğin, İngiliz ve Irak hükümetlerince desteklenmesi temennisi yer almaktadır. Ancak bu temenni ile yanlış anlaşılmaların önüne geçmek adına bildirgenin en sonunda Kongre, Ingiltere, Fransa, Suriye, Iran ve Irak hükümetlerine, Türkiye'de baskrya uğrayarak göçe mecbur bırakllan Kürt mültecilerini sevgiyle kabul etmişs olduklarından ötürü minnettarlıklarını (Kurubaş 1997: 176) sunduğunu ifade etmiştir.

\section{Kürt-Ermeni Bă̆lantısı}

Hoybun Örgütü'nde Ermenilerin hangi düzeyde rol aldığı tartışmalı bir konudur. Kimi yazarlara göre (Yıldız 1992: 217, Cöhçe, 2000:523) Ermeniler örgütün kuruluşundan itibaren son derece etkindirler ve bu etkiyi örgütün isminde de görmek mümkündür. Hatta Hoybun bir Kürt-Ermeni örgütüdür. Ancak buna karşı çıkan görüşe göre (Alakom 1998: 19-20) ise Hoybun, Ermenilerle dostane ilişkiler geliştirmeye çalışmakla ve onların desteklerini almakla birlikte kesinlikle bir Kürt örgütüdür.

Hoybun daha kuruluş aşamasındayken Memduh Selim'in Ermenilerle ilişki halinde olduğu sıklıkla dile getirilmektedir (Göktaş 1991: 93; Kurubaş 1997: 172, Aytepe 1998b:50). Ermenilerle ilişkileri geliştirmek için uğraşan başka bir isim Süreyya Bedirhan'dır. Hoybun'un hazırlık toplantılarına katılan isimler arasında bazı Ermeni Taşnak Örgütü mensuplarının isimleri de zikredilmektedir. Temasların bir sonucu olarak, Vahan Papazyan yerel Kürt liderleri ile görüşmek üzere Suriye ve Irak'a gitmiştir (Alakom 1998:107). Şadillili (1980: 166) Hoybun'un ilk toplantısına Levon, Emirizyan, Sultanyan ve Ariş adlı Ermeni önderlerinin katıldığını, bu toplantılardan sonra Paris'te bir toplantı yapılmasına ve bu arada Milletler Cemiyetine başvuru için aşiretler adına birer heyet gönderilmesine karar verildiğini yazmaktadır. Buna göre; Suriye Kürtlerini Hüsnü, Irak Kürtlerini Şerif Paşa ve diğer Kürtleri de Dr. Mehmet Şükrü temsil etmek üzere Paris'e gönderilmişlerdir. Ermeni Heyetinde ise Ropen Papazyan ve Boğas Nubar Paşa vardır. Ayrıca Erivan heyetinden Ahadisyan ve Vahoranyan bulunmaktadir.

\footnotetext{
${ }^{5}$ 11-16.maddeler arasında askeri örgütlenme öngörülmekte ve bu yönde düzenlemeler yapılmakta, propaganda faaliyetleri ise 9. ve 16 ila 19. maddeler arasında detaylı bir şekilde ele alınmaktadır. (Karaca 2003: 20-21; Alakom 1998: 26)
} 
Hoybun'un bir Kürt-Ermeni örgütü olduğunu ileri sürenler kimi kaynaklara göre ilk başkan olarak Vahan Papazyan seçilmiştir (Şadillili 1980: 168-169, Kalafat 1992: 137). Papazyan'ın Hoybun'un ilk başkanı olup olmadığı konusu tartışmalı bile olsa, kendisinin ilk merkez komitede yer aldığı bilinmektedir. Bazı kaynaklara göre ise, Taşnak Örgütü'nün Suriye'deki temsilcilerinden Hratcth Papazyan, Hoybun'un Halep biriminin daimi üyelerinden biri olmuş ve Celadet Bedirhan'dan sonra örgütteki en etkili kişilerden biri haline gelmiştir (Alakom 1998: 107; Göktaş 1991: 94). İhsan Nuri, anılarında, isyan sırasında Ermeni Taşnak Örgütü adına Ardeşir Muradyan isimli bir temsilcinin, Ağrı'ya geldiğini yazmaktadır (İhsan Nuri Paşa 1992: 29-30).

Hoybun ile Taşnak örgütü arasındaki ilişkileri ortaya koyan en önemli belge 1927 yılında Paris'te yapılan toplantı sonrasında iki örgüt arasında imzalanan mutabakattır. $\mathrm{Bu}$ mutabakatta, biri Kilikya'da öteki Erivan'da olmak üzere iki Ermeni devleti ve bunların arasında bir Kürdistan'ın kurulması konusunda anlaşmaya varılmıştır (Şadillili 1980: 166, Yavuz 2005:81, Şimşir 2009:76, Alakom 1998:133). Anlaşmanın özellikle bazı maddeleri iki örgüt arasındaki ilişkilerin düzeyini anlamak bakımından önemlidir. 6. madde Hoybun'un mali alanda geçici olarak desteklenmesine ayrılmıştır. Anlaşmanın 10. maddesi silah yardımını ele almaktadır. 8. maddeye göre Taşnak Örgütü’nün Avrupa'daki ve Amerika'daki elemanları aracılığı ile Kürt sorununu destekleyecektir ve ayrıca Hoybun'un merkez komitesinde Taşnak Partisi'nden bir temsilci yer alacaktır. Bu anlaşma, Hoybun içindeki Ermeni üyelerin varlığını ve konumlarını anlamak açısından önemlidir. Nitekim Ermenilerle kurulan bu yakınlık ilk Kongre kararlarına da yansımıştır. Kongre'de Ermenilerle olan bütün yanlış anlama ve anlaşmazlıkların ortadan kaldırılmasına karar verilmiştir (Kurubaş 1997: 176). Ayrıca Kongre'nin sonuç bildirgesinde Ermenistan ve Kürdistan'da yüzyıllardır Ermeni ve Kürtler yaşamaktadır ve onlar bu toprakların başka devletlerin eline geçmesine kesinlikle karşıdırlar ifadesi yer almaktadır (Kurubaş 1997: 176).

Hoybun'un kuruluşunda Ermenilerin Kürtlere verdiği destek İngiliz gizli belgelerinde de ifade edilmiştir. "Yarbay Dodd'dan Sir R.Glive'a" başlıklı 28 Haziran 1930 tarihli 59 nolu kapalı evrakta, Yarbay Dodd “(...)1914'te Ermenistan Savaş Bakanı olduğunu bildiren Ruben Paşa isimli bir zatla randevulu olarak buluştum. Ingiliz ve Iran hükümetlerinden A ğrı'daki

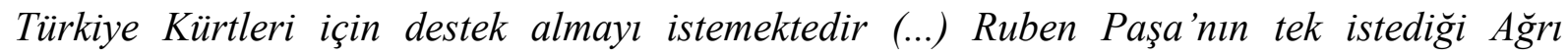
Kürtlerine gayriresmi olarak cephane temin edilmesidir" bilgisini vermektedir (Kalman 1997: 46-48).

Ermenilerin örgüt içinde sahip oldukları bu etkinlik kimi Kürt ileri gelenleri rahatsız ederek, daha kuruluş aşamasından örgütten ayrılmalarına neden olmuştur. Özellikle Şeyh Sait ailesine göre Ermenilerin Kürtlerle kurmaya çalıştığı dostluk samimi değildir. Şeyh Sait'in kardeşi Şeyh Mehdi rahatsızlığı şu sözlerle dile getirir (Kaya 2001): "Buraya kadar oynanan oyunun mahiyeti artık anlaşılmıştır. Şu şekle bakınız iki Ermenistan ve ortada iki yumruk arasında kalmış bir Kürdistan... Bunu hangi akıl kabul eder? Sonra kurulan cemiyet, bir Kürt cemiyeti olduğu halde reis Ermeni oluyor. Kürtler gizli bir planla ortadan kaldirlmak isteniyor. Ben Ali Rıza ve taraflarımız adına şimdiye kadar verilen kararların hiçbirini kabul etmiyorum." Cegerxwin (2003) anılarında ise; Taşnakların bir yandan Kürt örgütlenmesine yardım ettiklerini, öte yandan resmî haritalarında Kürdistanı Ermeni toprağı olarak 
gösterdiklerini; Ermeni halkına ise "Doğrudur, paralart sizden alıp Kürtlere veriyoruz. Ama şunu bilin ki amacımız iti ite kırdırmaktır" dediklerini aktarmaktadır. Bu görüşü paylaşanlara göre; Taşnak Partisi'nin Hoybun'a olan desteği, onu etkisi altına almakla sonuçlanmıştır. Taşnakların Hoybun'u desteklemesinin en önemli nedeni, Türk topraklarında herhangi bir silahlı eyleme girişemeyeceklerinden dolayı, Kürtleri kullanmak istemeleridir. Ayrıca Taşnaklar, "Türkiye Kürdistanı”nı "Büyük Ermenistan”ın parçası olarak gördükleri için Hoybun'a yapılan destekle Türkiye'deki "Ermeni topraklarını" da kurtarabileceklerini düşünmüşlerdir. Böylece onlara bağımsız bir Kürt devletinin "bağımsız ve büyük" Ermeni devletinin temeli olacağını ummuşlardır (Kurubaş 1997: 177, Sarınay 1998:6).

Ancak Ermenilerle ittifakın zorunlu olduğunu dile getirenler ve savunanlar da mevcuttur. Cemilpaşazade Kadri, Kürtler'in seslerini dünyaya duyurabilecekleri bir yayın araçlarının olmadığını ve uluslararası camiada yalnız olduklarını bu nedenle bu ittifakın gerekli olduğunu; ayrıca aleyhlerine yapılan propagandaya son verileceğini ve bunun da önemli bir gelişme olduğunu belirtmektedir (Kurubaş 1997: 172). Dersimi de benzer şekilde bir takım zaruretlerin telafisi için Hoybun'un Taşnak Örgütü ile işbirliği yapmak zorunda kaldığını görüşündedir (Dersimi 1992: 92). Ermenilerin Avrupa'da ve Amerika'daki etkinlikleri düşünülürse bu ittifakın örgüte özellikle yurtdışında sesini duyurma açısından önemli bir imkân sağladığı aşikârdır. Ayrıca kendi aleyhlerine olan propagandayı durdurabilmiş olmaları da önemli bir kazançtır. Bununla birlikte, bu ittifakın örgüte zararlar verdiği noktalar da olmuştur. Her şeyden önce bazı Kürt ileri gelenlerinin bu nedenle örgüte kendilerini yakın hissetmemesi ve şüphe ile bakması, örgütün kapsayıcılığına ve etkisine zarar vermiştir.

\section{Yabancı Devletlerle İlişkiler}

Hoybun Örgütü’nün kurulduğu ve yoğun olarak faaliyetlerini yürüttüğü yer o dönem Fransız mandası altında olan Suriye ve İngiliz mandası altında olan Irak’tır. I. Dünya Savaşı sırasında ve sonrasında dönemin iki büyük gücünün çıkar mücadeleleri sahne olan bölgede, bir Kürt örgütünün faaliyetlerini ve hatta varlığını bu iki devletten habersiz sürdürmesi olanaksızdır. Bölgedeki etkinlik mücadelesine bu devletlerin çıkarlarını tehdit eden Sovyet Rusya'yı da dâhil etmek gerekmektedir. Söz konusu devletler arasında her platforma taşınan çekişmenin yansımaları Hoybun Örgüt'ü üzerinde de kendisini göstermiştir. Ağırlıklı olarak üzerinde durulan iddia Hoybun'un İngilizlerin desteği ve hatta bizzat onların planları ile kurulan bir örgüt olduğudur. Buna göre; İngilizler, Ermenilerle Kürtleri bir çatı altında toplayacak bir örgütü hayata geçirmek için her iki tarafın da önde gelenleri ile görüşmüşler ve toplantılara bizzat katılmışlardır (Yıldız 1992: 217, Cöhçe 2000:523, Yavuz 2005:22). Seyit Taha'nın evinde yapılan ilk toplantıda İngilizler adına, Irak Olağanüstü Komiser Yardımcısı ve Entelijans Servisi mensubu Edmonds, toplantının planlayıcısı olan İngiliz Elçiliği’nden Kaptan Moltfoltre ve kâtibi yer almıştır. Alınan karara göre; İngilizler Kürtlere para ve gerekirse silah yardımı yapacak, Nasturilere destek verecek, Hoybun'un Türkiye'ye Şemdinan bölgesinden başlatacağı taaruzun Van'1 işgaliyle sonuçlanması halinde yardımda bulunacaklardır (Kalafat 1992: 134; Öznur 2003: 271, Yavuz 2005:19). İngiliz etkisine yer veren başka kaynaklarda ise Beyrut'ta yapılan Hoybun toplantısına Ali Rıza'nın gelmesine 
Fransızlarla ilişkisi olduğu gerekçesi ile İngilizlerin engel olmak istedikleri ileri sürülmektedir. Çünkü İngilizler bu kadar emek verdikleri Hoybun'un Fransızların eline geçmesini istememektedirler (Şadillili 1980: 167). Bu görüşü destekler biçimde bu dönemde Sovyet ve Alman basınında, İngiltere'yi Hoybun'u desteklemekle ve bölgede ayaklamaları kışkırtmakla suçlayan yazılar çıkmıştır (Karaca 2003: 181, Koçaş 1990:319). Nitekim Türkiye Hükümeti de Şeyh Sait isyanında olduğu gibi, Ağrı İsyanı'nda da İngilizleri Kürtleri isyana teşvik etmekle itham etmiştir (Jwaideh 2003: 415). 9 Nisan 1931 tarihli I. Umumi Müfettişlikçe yazılan rapora göre İngiltere'nin bölgedeki aşiretler ve gelişmelerle yakından ilgilenmesinin nedeni “Hakkari vilayeti ile Cizre'de dahil olmak üzere, Irak Kürtleri hakimiyeti altında Irak ile Türkiye arasında bir Kürt hükümeti teşkil etmek”tir (BCA, 030.10.115/796/20).

İngilizler ise Kürtlere destek verdikleri yönündeki iddiaları kesinlikle reddetmişlerdir. 1930 sonlarında Sömürgeler Bakanı Lord Passfield'e yazdığı gizli raporda Bağdat Yüksek Komiser Humphrys, Ankara'ya yaptığı ziyaret sırasında, İngiltere'nin Kürt bağımsızlık fikrini asla teşvik etmediği ve Irak'ın Türkiye'ye karşı bir üs olarak kullanılmasına müsaade etmeyeceği konusunda Türk devlet adamlarına güvence verdiğinden söz etmektedir (Şimşir 1975:250). Bir başka İngiliz belgesinde, Yarbay Dodd'un Sir R.Glive'a gönderdiği raporda, Yarbay Dodd, Ermeni Ruben Paşa'nın Ağrı'daki Kürtler için cephane talebini aktardıktan sonra “(...) bu istemin gülünç olduğunu, Majesteleri’nin bakanına konudan ciddi bir şekilde söz etmeyeceğimi bildirmek zorunda kaldım” demektedir (Kalman 1997: 45).

Peki bu iddialar yersiz midir? Belgeler, İngilizlerin en azından kuruluş aşamasındaki toplantılara katıldığını ve çeşitli kereler Ermeni ve Kürt temsilcilerle irtibat kurduklarını göstermektedir (Şimşir 1975, Yavuz 2005). Ancak Hoybun'un faaliyet gösterdiği dönemde İngiltere'nin Türkiye üzerinde baskı kurmak amacıyla böyle bir örgüte ön ayak olmak ve bölgede bir ayaklanma çıkarmak için yeterince güçlü bir nedeni bulunmamaktadır. 1923 İzmir İktisat Kongresi Türkiye'nin Batı yanlısı bir politika izleyeceğini ve komünist bir sisteme kaymayacağını göstermiştir. Bölgedeki Kürtlere yönelik İngiliz politikaları önceleri çeşitlilik göstermekle birlikte, Sevr Antlaşması ile birlikte netlik kazanmıştır. Buna göre birleşik bir Kürdistan fikrinden tamamen vazgeçen İngiltere, Kürdistan'ın Kuzey ve Güney olarak bölünmesine razı olmaktadır. Bunun ardında yatan neden ise açıktır; İngiliz çıkarları için petrol bölgesi olan güneydeki Musul'u elde tutmak gereklidir. Buna karşılık, Türkiye sınırları içinde olan kuzey bölgesinde hem petrol yoktur, hem de arazi denetlenemez dağlik bir yapıdadır (Uzgel 2003: 259). İngiltere ile Türkiye arasında sorun olabilecek Musul, 1926 senesinde İngiltere lehine çözüme kavuşmuştur. Dolayısıyla iyi ilişkilerin kurulmaya başladığı ve sorunların kendi lehine çözüldüğü bir dönemde İngiltere'nin bir Kürt örgütünün kuruluşuna ön ayak olduğu, ciddi bir mali destek ve cephane sağladığı iddiaları aşırı gözükmekle birlikte, bölgede gelişen Kürt hareketlerine kayıtsız kalmayacağı aşikardır. Bu nedenle İngiltere'nin gerekirse böyle bir oluşumu kontrol edebilmek ve yönlendirmek maksadıyla yakından takip etmiş, ilişki kurmuş, sınırlı yardım ve vaatlerde bulunmuş olması daha muhtemeldir.

Hoybun üzerinde etkinliği olduğu ve destek verdiği ileri sürülen bir diğer devlet ise Fransa'dır. Burada özellikle Ermeni-Fransız yakınlı̆̆ına vurgu yapılmaktadır (Yavuz 
2005:22). Hoybun'un hazırlık toplantıları İngiliz kontrolündeki Irak'ta yapılırken, kuruluş kongresinin Lübnan'da yapılmış olmasını örgütün Fransız kontrolüne girmesi olarak yorumlayan görüşler mevcuttur (Sarınay 1998). Buna göre, Hoybun'un kurulması ile Suriye'de Fransızlar ve Kürtler arasında kurulacak yakın ilişkinin temeli atılmıştır (Jwaideh 2003: 278). Fransızlar Hoybun'a bölgedeki Kürtleri Fransız yanlısı fikirlere yöneltmeleri için Suriye'yi üs olarak kullanma izni vermişlerdir. Fransız etkisi o kadar büyüktür ki; II. Dünya Savaşı sırasında Fransızlar Hoybun'dan, Türk karşıtı faaliyetleri durdurmalarını istemiş ve bu öneri kabul edilmiştir (Jwaideh 2003: 278). Fransa'nın Ağrı İsyanı'nın arkasındaki güç olduğu da ileri sürülmektedir. Bu görüşü destekler şekilde, Dahiliye Vekaletine 6 Haziran 1928 'de gönderilen yazıda Fransızlar'ın Türkiye'nin güney sınırlarında Kürt ve Ermenilerden silahlı çeteler oluşturduğu bunların yakında Türkiye'ye karsı harekete geçecekleri rapor edilmektedir (BAC, 030.10.115/803/3). Ayrıca 12 Nisan 1931 tarihli başka bir raporda Fransızların Ağrı, Barzan, Mutki ve Cizre mıntıkasına tahsis edilecek silah ve cephane alınması icin Vahan Papazyan'a 10 milyon Frank verdiği bilgisi verilmektedir (BAC, 030.10.115/796/20). Fransızlar'ın bu desteğinin nedeni Kurubaş'a göre (1997: 180) isyan ile Türkiye'ye baskı yapabilmek ve Hatay ile ilgili tavizler koparmaktır. Şadillili (1980: 165) ise Hoybun'u Fransızlar'ın Suriye'deki çıkarlarını korumak için desteklediğini ileri sürmektedir. Bütün bunlara karşı1lık, Fransızların hiç bir şekilde Hoybun'a destek vermedikleri ve tam tersi engel olmaya çalıştıklarını savunan görüşler de mevcuttur. Buna göre, Suriye'deki Fransız yönetimi Hoybun'un faaliyetlerinde güçlük çıkarmış, bu yüzden örgüt faaliyetlerini gizlilik içinde yürütmek zorunda kalmıştır (Alakom 1998: 13).

Fransa'nın, İngilizler'e benzer şekilde Hoybun'un faaliyetlerden haberdar olması kaçınılmazdır. Her ne kadar Fransızların Hoybun toplantılarında yer aldığı bilgisi yoksa da İngilizlerin devrede olduğu ve Hoybun'un uluslararası destek aradığı bir ortamda Fransızların temasa geçmemiş olması düşünülemez. Nitekim örgütün Fransızlarla yakın ilişki içinde olduğu görülmektedir. Fransa'nın Hatay Sorunu konusunda baskı yapabilmek amaciyla Hoybun'u desteklemiş olması mümkün gözükmektedir. Ancak Fransa'nın Türkiye'nin Ortadoğu'daki etkinliğini azaltmak için Türkiye'ye karşı faaliyet gösteren Ermeni ve Kürtlere destek verdiği yönündeki tez (Yavuz 2005:30) ise güçlü dayanaklardan yoksundur. Bu dönem Türkiye'nin Ortadoğu ile ilişkileri son derece kısıtlı ve Arap ülkelerine karşı tutumu ise mesafelidir. Ayrıca 1926'da Fransa ile Türkiye arasında 'Dostluk ve İyi Komşuluk Sözleşmesi'nin imzalanmıştır. Bu da iki ülke arasında Hatay Sorunu'nun kısmen yoluna girdiği ve ilişkilerin düzeldiği bir dönemin başlangıcıdır. Savaştan yorgun çıkan Fransa için bölgedeki statükoyu değiştirebilecek Kürt isyanları, Suriye'deki mevcut nüfuzunu da sarsma potansiyeline sahiptir. Dolayısıyla Fransa her ne kadar örgüte destek vermiş ve kontrol çabası içine girmişse de Hoybun'un Fransız planı ile kurulmuş ve ayaklanma başlatmış olduğu tezi, Kürtlerin ve Ermenilerin fikir ve faaliyetlerini ihmal etmektedir.

Hoybun ile ismi anılan bir diğer ülke Sovyetler Birliği’dir. Bu dönemde, Sovyetler Birliği, İngiltere'yi bölgedeki Kürt isyanlarını desteklemekle suçlarken; aynı suçlamaları İngiliz basını da Sovyetler için yapmıştır (Sasuni 1989:206-207; Yıldız 1992: 230). Kimi kaynaklara göre 1928'de Odessa'da SSCB tarafından desteklenen Uluslararası Azınlık Hareketleri Cephesi Ermenilere, Kürtlere ve anti-Kemalist Türklere mali yardımlarda bulunmuştur. Nitekim bu dönemde isyancı Kürtlerin kullandığı bazı silahların Sovyet yapımı 
olması nedeniyle Türk Hükümeti tarafından da Sovyetler'in destek sağlayan ülkeler arasında görüldügü ileri sürülmektedir (Kurubaş 1997: 180). Ancak bu görüşlere karşın, Sovyetler'in Hoybun Örgütü'ne karşıt bir tavır takındığı fikri daha güçlüdür. Buna göre, Hoybun’u emperyalist güçlerin bir planı olarak değerlendiren Sovyetler, özellikle Sovyet karşıtı görüşleri ile tanınan Taşnaklar'ın Hoybun'a verdikleri destek konusunda rahatsızdır (Alakom 1998: 13). Nuri Dersimi (1992: 253) de Sovyetlerin bu konudaki rahatsızlığına değinmiş ve Ağrı İsyanı'nda bir İngiliz veya Fransız parmağı olduğu yönündeki Türk iddialarının Sovyetlerce de desteklenmesini buna dayandırmıştır. Sovyetlerin Ermeni Taşnak Örgütü’ne karşıt tutumu ve bu dönemde Türkiye ile kurduğu yakın ilişkiler göz önüne alındığında; Hoybun'un faaliyetlerinden rahatsızlık duyuyor olması güçlü bir ihtimaldir. Cegerxwin anılarında, Ağrı isyanı sonrasında Kürt isyancıların Sovyetler Birliği’ne sığınmak istediklerini ancak Sovyetlerin buna izin vermediğini ileri sürmüştür. Cegerxwin'e göre (2003: 226), Sovyetler, ilerici gördükleri Türk Hükümeti'ni desteklemekte ve Kürt hareketlerini ise "emperyalistlerin uşă̆l, özellikle İngilizlerin işbirlikçisi, gerici hareketler" olarak görmektedirler.

Yukarıda değinilen bütün bu iddialara karşıllk Hoybun Örgütü 12 nolu bildirisinde, yabancı devletlerle ilişkisini Hoybun hiç bir devletin siyasi aleti değildir ve olamaz sözleri ile özetlemektedir (Karaca 2003: 27). Bunu destekler şekilde Dersimi (1992: 254) İngiliz ve Fransızların örgütü istismar ettiklerini ve fiili yardımdan bulunmaktan titizlikle kaçındıklarını, hatta Türkiye ile ilişkileri düzelince, Hoybun'un etkinliklerini engellediklerini belirtmektedir. Garo Sasuni (1989:206-207) Kürt hareketinin hiç bir yabacı devletin yardımını almadığını, halbuki Türklerin Sovyetlerle işbirliğini yaptığını, İranlıların ise son dakikada Türklere yardım ettiğini söylemektedir. Sasuni'ye göre, Irak ve Suriye'de İngilizler ve Fransızlar ise bu harekete düşmanca bir tavır takınarak Kürt ulusal hareketinin güneyden herhangi bir yardım alma olanağına engel olmuşlardır. Sovyetler İngilizleri, İngilizler Sovyetleri suçlarken, her ikisi de bu konuda her hangi bir belge sunamamaktadır.

Ağrı isyanı sırasında Kürt isyancıların, İran tarafından desteklendiği, en azından Türk kuvvetleri tarafindan sıkıştırılınca İran'a kaçarak, tekrardan toparlanarak saldırdıkları bilinmektedir. O dönem Türk basınında da bu yönde ifadelere sıklıkla rastlanmaktadır (Karaca 2003: 37, 39-44, s.90). Ancak İran Hükümeti, kendisine yöneltilen bu suçmaların hiç birini kabul etmemiştir (Kurubaş 1997: 182). Diğer yabancı devletlerle ilgili iddialar kesinlik taşımamakla birlikte, Hoybun'un en azından Ağrı İsyanı sırasında İran tarafından kollandığı açıktır. 5 Temmuz 1930 günü Cumhuriyet gazetesi İran Hükümeti'ne bu konuda bir nota verildiğini manşetine taşımıştır (Karaca 2003: 41). Nitekim Türk kuvvetleri, İran'dan gelen bu desteğin önünü kesmek için İran topraklarına girerek Küçük Ağrı Dağı'nı işgal etmiş ve iki ülke arasındaki sorun daha sonra bir sınır düzenlemesi ile çözülmüştür. İsyan bastırıldıktan sonra kaçan Kürtler ise sığınmak için yine İran’a geçmişlerdir (Oran 2003: 253). 


\section{Faaliyetler}

\section{Yayınlar ve Propaganda Çalışmaları}

Hoybun Örgütü'nün en başarılı olduğu ve hiç şüphesiz onu Kürt örgütlenmeleri içinde ön plana çıkaran alan yoğun yayın faaliyetleridir. Kuruluşundan itibaren örgütün iki stratejisi vardır. Biri askeri mücadele, bir diğeri ise propaganda çalışmalarıdır. Hoybun Tüzüğü'nün 'Propaganda' başlıklı bölümünde yapılacak çalışmalar düzenlenmiştir. Buna göre, Türk mezalimini ve Kürt ihtilali hakkında yapılacak propaganda şifahi ve tahriri olarak icra edilecektir. $\mathrm{Bu}$ amaçla, mintıka ve şubelerde birer propaganda memurunun bulundurulması öngörülmektedir (Alakom 1998: 130, 139).

9 Mayıs 1928 'de, Türkiye Cumhuriyeti Şeyh Sait isyanı ardından başlattığı sürgünlere son vererek, genel bir af ilan etmiştir (Kalman 1997: 67-68). Affı izleyen dönem, Hoybun ile bölgedeki Genel Müfettişlik arasında propaganda savaşına dönmüştür. Müfettişlik affı duyurmaya çalışırken, Hoybun da Kürt halkı affa inanmasın diye faaliyetler yürütmüştür. Örgüt, Mart 1928'de affa karşı yayınladığı ilk bildiride affa inanmama ve birlik olma çağrısını daha sonra slogan olarak kullanacağı "Bexte Rome Tuneye!” (Türkülerin vicdanı yoktur) sözleri altında yapmaktadır. Bu bildiride Türk hükümetinin amacı, Türkiye sınırları dışında yaşayan Kürt milliyetçileriyle, halen dağlarda isyan halinde olan içerideki Kürtleri hile ile ele geçirmek olarak yazılmıştır. Bunu affa karşı halkı uyaran diğer bildiriler izlemiştir (Kalman 1997: 23-26). Bildirilerin içeriğine bakıldığında, bunlarda sadece af konusu işlenmediği görülmektedir. Hoybun, amaçlarına uygun olarak, halkı bilgilendirme gayreti ile yayınlarında Kürt tarihine, isyanlarına yer vermiş ve Kürt kimliği vurgulamıştır.

1928 yılı içinde Hoybun, Kürt Hoybun Örgütü'nün Dünyaya Çağrısı: Kürtlerin Kırımı başlıklı bir bildiri daha yayınlamıştır. "Uygar devletleri” Kürt sorununa sessiz kalmamaya çağıran bu bildiride, tarihi bir akış içinde Kürtlerin verdikleri mücadele ve Kürt isyanları anlatılmaktadır. Şeyh Sait isyanı sonrası görülen davalardan bölümlere yer verilerek Avrupa ve Amerika'dan heyetlerin bölgeye gelerek Kürtlerin durumunu görmeleri talep edilmektedir (Bayrak 1994: .40-56). Hoybun Örgütü, yayın çalışmalarını başta belirlediği programa uygun olarak çeşitli ülkelerde yürütmüş ve çıkardığı değisşik broşür, dergi ve kitapları Türkçe, İngilizce, Fransızca ve Arapça olarak yayımlamıştır. Yayın etkinlikleri büyük ölçüde Mısır'dan yürütülmüştür (Alakom, 1998: 60). Bunun yanı sıra Beyrut, Halep, Paris, Detroit, Indiana ve Philadelphia gibi merkezlerde de yayınlar çıkarmıştır (Kurubaş 1997: 177, Aytepe, 1998b: 53) Özellikle Dr. Mehmet Şükrü'nün ve Bedirhanların bu yayınların pek çoğunun altında adları bulunmaktadır. 1928 yılında Kahire'de The Massacres of Kurds in Turkey başlıklı bir rapor basılmıştır. Aynı yıl Philadelphia'da Süreyya Bedirhan tarafından, The Case of Kurdistan against Turkey adlı bir rapor daha yayımlanmıştır. Kadri Cemilpaşa, Hoybun'un, 1930'da Kahire'de Kürdistan'da yapılmakta olan ihtilal hareketlerinin nedenlerini açıklayan ve Kürt haklarını savunan Arapça El-Kaziyeyi Kürdiye, Fransızca La Question Kurde ve bir de İngilizce olmak üzere üç kitapçık çıkararak dünya kamuoyunu bilgilendirdiğini söylemektedir (Kurubaş 1997: 179-180). Aynı yıl, Celadet Bedirhan tarafından "Kürt Sorununun Kökleri ve Nedenleri” başlıklı uzun bir makale kaleme alınmıştır. Amaç yine Kürtlerin sesini dünyaya duyurmaktır (Bayrak 1994: 57-101). 1932'de Celadet Bedirhan 
Şam'da, Hawar ve Ronahi dergilerini, Beyrut'ta ise Roja $N u$ adlı bir gazeteyi yayımlamış, pek çok makale ve kitap kaleme almıştır. Örgüt tarafından Beyrut'ta ayrıca Sur, Bağdat'ta ise Gelavij dergileri yayımlanmıştır (Aytepe, 1998a: 57). Celadet Bedirhan örgütten ayrıldıktan sonra bağları koparmamış ve yayınları ile Hoybun'un amaçlarını desteklemiştir. 1932'de resmen ilan edilen sürgün yasasını eleştiren ve analiz eden Kürt Sorunu Üzerine: Kürtlerin Sürgün Edilmesi ve Dağıtılması Yasası (De La Question Kurde: La Loi de Deportation et de Dispersion des Kurdes) isimli kitabı Fransızca olarak yayımlanmıştır. (Ekrem Cemil Paşa 1989:74). Hoybun için propaganda o kadar önemlidir ki Ağrı isyanı sırasında Hoybun bölgeye bir matbaa makinesi göndermiştir. İhsan Nuri, bu dönemde A $\breve{g r} l$ ve Gaziya Welat isimlerinde gazeteler çıkararak hareketin propagandasını yapmaya çalışmıştır. Ayrıca Agrı Egir Dibarine (Ağrı Ateş Yağdırıyor) başlıklı bir bülten çıkarılarak, ayaklanmanın amaçları anlatılmıştır (Göktaş 1991: 94).

$\mathrm{Bu}$ dönemde propaganda faaliyetlerini sadece yayınlarla sürdürülmemiştir. Örgüt, bu faaliyetler için Taşnak Partisi adına Paris bürosundan Çamlayan'ı; Hoybun adına da Süreyya Bedirhan'ı görevlendirmiştir. Bu görevlendirme üzerine Çamlayan, Yunanistan, Bulgaristan, Romanya ve Mısır'da ziyaretlerde bulunarak konusmalar yapmış ve mali kaynak temin etmiştir. Hoybun da, Süreyya Bedirhan'ı ABD’ye göndermiş, kendisi Detroit (Michagen), Chicago (Illinois), Gary ve Whiting (Indiana)'da örgütün şubelerinin kurulmasına öncülük etmiştir. Çeşitli şehirlere ziyaretler yapan Süreyya Bedirhan Ermenilerin de desteği ile Hoybun için yardımlar toplamıştır. Bu faaliyetler 1936 yılına kadar sürmüştür (Aytepe,1998a: 57-58). Hoybun bu dönemde ayrıca Kürtlerin içinde bulunduğu durumu aktarması için Milletler Cemiyeti'ne bir temsilci heyeti göndermiştir. Bunun yanısıra Hoybun'un temasları sonucunda 1930 yılında İsviçre'nin Zürih kentinde toplanmış olan II. Sosyalist Enternasyonal, Kürtlerin baskı altında tutulmasını protesto eden bir bildiri de yayınlamıştır (Jwaideh 2003: 413). 1939-1946 yılları arasında Hoybun'un siyasi temsilciğini yürüten Cemilpaşazade Ekrem, kendi döneminde her fırsatta büyük küçük devletlerin yardımını istediğini ve bu ülkelere kendi çizdiği Kürdistan haritasını takdim ettiğini, San Francisko Konferansı'na Beyrut'tan çeşitli telgraflar çektiğini yazmaktadır (Ekrem Cemil Paşa 1989: 77-80).

Hoybun'un yayınları Ağrı isyanın başarısızlıkla sonuçlanmasının ardından yavaşlamaya başlamıştır. Bununla birlikte örgüt üyelerin veya örgütü destekleyenlerin yayınlara kişisel olarak devam ettikleri görülmektedir. Hoybun etkin olduğu 1927-1934 y1lları arasında toplam 71 tane periyodik olmayan yayın yapılmıştır. Bunların yıllara göre dağılımı şöyledir; 1927'de 15, 1928'de 5, 1929'da 7, 1930'da 7, 1931'de 8, 1932'de 6, 1933'de 11, 1934'te 12 (Kurubaş 1997: 186). Buradan da görülmektedir ki; Hoybun yoğun bir yayın politikası izlemiştir. Bu yönüyle, Kürt hareketinin sesini dünyaya duyurmasına ön ayak olmuş ve yeni bir dönem başlatmıştır.

\section{A $\breve{g r l} \dot{I}$ syanı}

Hoybun Örgütü'nün bağımsız bir Kürt devletini hayata geçirmek için öngördüğü stratejinin ikinci ayağını 'askeri mücadele' oluşturmaktadır. Tüzük'te 'Teşkilat-1 Askerîye ve Çeteler' başlı̆̆ 1 altında 11-17. maddelerde örgütün askeri kanadına ilişkin düzenlemeler yapılmıştır (Alakom 1998: 129). Hoybun, hedeflerine uygun aradığı askeri mücadele 
zeminini, Ağrı'da bulmuştur. Bu dönemde, Şeyh Sait İsyanı sonrasında dağlarda küçük çetelerin çatışmaların içinde oldukları bilinmektedir. Türk askeri birlikleri ile Biroyê Heskê Teli'nin [İbrahim Paşa] ${ }^{6}$ başında olduğu Kürt isyancılar arasında ilk çatışmalar 16 Mayıs 1926 tarihinde gerçekleşmiştir (Karaca 2003: 21). Bu nedenle bazı kaynaklarda Ağrı İsyanı'nın başlangıç tarihi ilk çatışmaların başlangıcı olan 1926 olarak gösterilmektedir (Kalman 1997: 26; İhsan Nuri Paşa 1992: 16). Bazı kaynaklara göre ise ayaklanma Hoybun kurulduktan sonra, 1927 yılında başlamış ve 1930 yılına kadar sürmüştür (Alakom 1998: 65). İsyan sırasında en yoğun çatışmalar 1930 senesinde yaşandığı için, Ağrı İsyanı'nın bu sene içinde başladığını ve kısa sürede bastırıldığını ileri sürenler de vardır (Yıldız, 1992: 220; Öznur 2003: 272).

Hoybun aslen Ağrı'da çetelerin başlattığı küçük çapta isyanları örgütlemeye yönelmiştir. Örgütün öncülügünde, Ağrı Dağı ve çevresinde büyüyen bu isyan, Kürt isyanları içinde en uzun süren ve zor bastırılan isyanlardan biridir. Ağrı'daki çatışmalardan haberdar olan İhsan Nuri, sığındığı Irak'tan kaçarak isyancıların yanına katılmıştır (Göktaş, 1991: 94). 1927'de toplanan Kürt Kurultayı'nda, Hoybun Örgütü Ağrı İsyanı'nın öncü kadrosunu oluşturmuş ve komuta kademesini şekillendirmiştir. İhsan Nuri, "Milli Hareketin Genel Kumandanı" seçilerek Ağrı'daki harekâtın başına getirilmiştir (Bayrak 1994: 89; İhsan Nuri Paşa 1992: 27). İhsan Nuri, harekât için Ağrı'da askeri örgütlenmeyi yürütmüştür. Dahiliye Vekaleti'nin Başvekalet'e gönderdiği 18 Temmuz 1929 tarihli yazıda Hoybun tarafından 20 bin kişilik bir askeri fırka oluşturulduğu yazmaktadır. Aynı raporda çete reislerinin tamamen Ermenilerden oluştuğu bilgisi de yer almaktadır (BCA, 030.10.115/803/5). İhsan Nuri’nin anılarından alt yapı oluşturulma yönünde de çaba sarfedildiği anlaşılmaktadır. Haberleşme için Ağrı'nın bir kaç köyüne telefon hattı çekilmiş, çetelere üniforma giydirilmiştir. Subayların üniformalarında Hoybun'un arması ve onun üstünde de kendi rütbelerini belirleyen armalar bulmaktadır (İhsan Nuri Paşa 1992: 47). Kürdistan Teali Cemiyeti'nin kabul ettiği ve Hoybun Komitesi tarafından Ağrı'ya gönderilen üç renkli Kürdistan bayrağı Ağrı Dağı'na dikilmiştir (İhsan Nuri Paşa 1992: 16). Ağrı'ya örgüt tarafından silah ve cephanenin yanı sıra bir matbaa makinesi gönderilmiştir. İhsan Nuri bir taraftan örgütlenme ile uğraşırken bir yandan da çıkardığı yayınlarla hareketin propagandasını yapmaya çalışırmıştır. Bütün bu örgütlenmenin arkasında Hoybun'un merkez komitesinin kontrolü olduğu görülmektedir. İhsan Nuri anılarında çeteler savaşı şeklinde yürütülen savaş taktiğinin ve stratejilerin bizzat Hoybun merkezince belirlendiğini aktarmaktadır. (İhsan Nuri Paşa 1992: 48). Nitekim Memduh Selim'in, Hoybun Örgütü Merkez Komitesi adına Ağrı yöresine gittiği ve isyanı yerinde incelediği ileri sürülmektedir (Alakom 1998: s.40).

Ancak Hoybun'un isyana bu boyutlarda katkı yapmadığını, yapamadığını dile getiren görüşler de vardır. Buna göre, Hoybun'un isyana desteği çok sınırlı kalmıştır. Bazı yerlere gerillalar göndermişlerse de örgütlenme olmadığından bunlar ciddi varlık gösteremezler. Ayrıca, Hoybun'un maddi destek, silah, cephane konularında yardımları olmadığını, böyle bir çalışma örgütleyebilmek için konumun uygun olmadığı ileri sürülmektedir (Kalman 1997: 289). Hoybun Örgütü’nün merkezinin, isyanın gerçekleştiği Ağrı'dan uzak oluşu, örgütün isyana verdiği desteği ve kontrolünü sınırlamış olmalıdır. Bu uzaklık dönemin koşulları göz

\footnotetext{
6 “Paşalık ünvanı Hoybun tarafından verilmiştir.” (İhsan Nuri Paşa 1992: 19-20)
} 
önüne alındığında bilgi akışının da sağlıklı olmadığını göstermektedir. Maddi yardım ve cephane yardımlarının yapılmış olması mümkün olmakla birlikte bunun önemli boyutlarda olması, yani Hoybun Örgütü'nün ciddi bir silah sevkiyatı gerçekleştirmiş olması zor gözükmektedir. Daha önce değinilmiş olan İngiliz belgelerinde de Ermeni Ruben Paşa'nın bu yöndeki teklifinin geri çevrildiği görülmektedir. Fransızların kısmi bir desteği söz konusu olsa bile İhsan Nuri de silahları esas olarak Türk kuvvetlerinden ele geçirdiklerini yazmaktadır. Maddi destek ve iletişim noktasındaki sıkıntılara rağmen İhsan Nuri ile örgüt arasındaki yazışmalar isyanın kontrolünde Hoybun'un olumsuzluklara rağmen etkin olduğunu göstermektedir (Karaca 2003: 28).

1930 kadar geçen süre içinde Türk Hükümeti Ağrı'daki isyanı kontrol altına almayı başaramamıştır. Ağrı, Hoybun tarafından "Bağımsız Kürdistan”ın bir vilayeti olarak ilan edilir. Biroyê Heskê Teli [İbrahim Paşa] Ağrı Valisi olarak atanırken, Vilayet Jandarma Komutanlığı'na Temir Ağa, Korhan Kaymakanlığı'na Molla Hüseyin Efendi, Koahan Kaymakamlığı'na Omerin Ağa, Ortili Nahiyesi Müdürlüğü'ne Hasan Efendi ve Kori Nahiyesi Müdürlüğü'ne de Musa Bekrili Ağa'nın atanmıştır (Göktaş 1991: 97). Hoybun'un, bir yandan askeri harekâta yön verirken, öbür yandan Ağrı'da idari bir yapılanma kurduğu görülmektedir. Bu gelişmeler üzerine, 28 Aralık 1929 tarihinde Cumhurbaşkanı Mustafa Kemal Atatürk'ün başkanlığında toplanan Bakanlar Kurulu Ağrı'da bir tenkil harekâtına başlanması yönünde karar almıştır (Göktaş 1991: 97). 1930 Haziran'ından itibaren Ağrı'daki çatışmalar şiddetlenmiş, Ağrı'da Türk kuvvetlerinin yoğun baskısı altında kalan İhsan Nuri'den gelen rapor doğrultusunda Hoybun, 30 Temmuz 1930 tarihinde yardım kararı almıştır (Kalman 1997: 99-100). Plana göre Mardin'den Derik kaza merkezine kadar olan cephede komutanlığı Cemilpaşazade Ekrem yapacaktır. Ancak bu grup, aşiretlerden isyan için gerekli desteği bulamamış ve merkeze geri dönmüştür. Diğer grupların başında bulunan Haco Ağa ve Celadet Bedirhan, arkadaşları ile beraber hareket istikametleri olan Heverka Dağı'na geçmişlerdir. Ancak onlar da Haco Ağa'nın hasımlarının muhalefeti nedeniyle bir şey yapamamışlardır. (Malmisanij, 2004: 125-126). Bu da isyanın sonunu hazırlamıştır. Türkiye Eylül 1930'da Küçük Ağrı Dağı'nı işgal ederek, isyancıları çevirmiş ve isyanı bastırmıştır. Ağrı İsyan'ı bastırıldıktan sonra bu isyana önderlik eden tüm kadrolar İran'a geçmişlerdir (Alakom 1998: 79).

\section{Hoybun'un Dăğlması}

Hoybun, kuruluşunda bütün Kürtleri bir çatı altında toplamayı ilke edinmiştir. Ancak daha ilk toplantılardan itibaren örgüt içindeki fikir ayrılıkları kendini göstermiştir. Ermenilerin örgüt içindeki varlıkları huzursuzluk yaratmıştır. Nitekim Seyit Taha ve Ali Rıza bu çatışmaların sonucunda örgütten ayrılarak, Hoybun'a mualif bir örgüt kurmuşlardır. ${ }^{7}$ İlk etaptaki bu ayrılışlar son olmamış ve ilerleyen yıllarda örgütten kopuşlar devam etmiştir. 1928 senesinde ilan edilen af kanunu, örgüt için ikinci bir darbe olmuştur. Bazı örgüt üyeleri bu af kanunu sonrasında gidip teslim olmuşlardır. Ciddi bir ayrılış olmasa da bu, örgüt içinde moral bozukluğuna neden olmuştur. (Alakom 1998: 99).

\footnotetext{
7 'Teali Cemiyeti' ya da 'Kürt Teali Cemiyeti' olarak adı geçmektedir. Ancak bu örgütün 1919'da İstanbul'da kurulan 'Kürt Teali Cemiyeti' ile bir bağlantısı yoktur.
} 
Kürtlerin aşiretler şeklindeki toplumsal yapısı ve bu aşiretler arasındaki çatışmalar pek çok zaman bağımsızlık hedefinin önünde önemli bir engel olmuştur. Hoybun Örgütü kurucuları bu sorunu 'kardeşlik andı' ile aşmaya çalışmışlardır. Ancak, bu kendi aralarındaki çatışmaları çözmelerine yardımcı olmamıştır. İlk günlerden itibaren örgüt içinde Bedirhanlar'ın ağırlığı hissedilmiştir. Ancak Celadet Bedirhan'ın başkanlığı tüm üyelerce benimsenmemiştir. Cegerxwin (2003: 190), anılarında örgüt üyelerinden Liceli Fehmi'nin kendisine "Sen daha çocuksun, Bedirxanların geçmişini bilmiyorsun. Onlarla yola çıkılmaz" dediğini aktarmaktadır. Örgüt içinde asıl çekişme ise, Cemilpaşazadeler ile Bedirhanlar arasında kendini göstermiştir. İlk başlarda ortak amaç için bir araya gelen bu aileler arasındaki görüş ayrılıkları özellikle Ağrı İsyanı'nın bastırılmasından sonra iyice su yüzüne çıkmıştır (Alakom 1998: 100).

Cemilpaşazade Ekrem (1989: 67) 1929 yılında merkezi Halep'e taşınan Hoybun’u dağılmış bir vaziyette bulduklarını ve idare heyetinde bulunan üç kişiden ikisinin, yani Celadet ve Kamuran [Bedirhan] Beylerin, Halep'i terk ederek Beyrut'a gittiklerini; Memduh Selim'in ise, Antakya'da öğretmenliğe başladığını belirtmektedir. Bu durum karşısında kendisinin amcazadesi olan Cemilpaşazade Kadri [Zinar Silopi] ile beraber örgütü derleyip topladıklarını ve yeniden etkinliğe geçirdiklerini aktarmaktadır. İki taraf arasında tatsızlıklar, 1932 yılında suçlamalara varmış, o yaz Hoybun temsilcileri bir toplantı yapmışlardır. Cemilpaşazade Ekrem (1989:77) Kamuran Bey’in kendisine verilen görevleri yapmadığı gibi, birçok suiistimale yol açtığını ve üç günlük sorgulama sonucunda örgütten uzaklaştırılmasına karar verildiğini ve bunun üzerine Celadet Bedirhan ve Haco Ăğa'nın da örgütten ayrıldıklarını ileri sürmektedir. Cemilpaşazadelerin zaten Haco Ağa ile aralarında eskiden beri problemler bulunduğu da iddialar arasındadır. (Cegerxwin 2003: 220-221). Tüm bu fikir ayrılıkları ve kişisel çatışmalar örgütten kopmalara neden olmuştur. Öyle ki, Hoybun Örgütü dağılmadan önce Merkez Komite'de ismi yer alanlar arasında, örgütün kuruluşunda bulunanlardan sadece Memduh Selim'in adı yer almaktadır. Bu durum, örgütü ciddi biçimde zayıflatmış ve dağılma sürecini hızlandırmıştır.

Dağılma sürecinde uluslararası ortam da etkili olmuştur. 1933'de Almanya'da Hitler'in iktidara gelmesi ile birlikte, dünya siyasetinde değişim kendini göstermeye başlamıştır. Bu süreç içinde İngiltere ve Fransa birbirine yaklaşırken, her iki ülkenin gözünde Sovyetler Birliği'ne komşu Türkiye'nin önemi artmıştır. Ağrı yenilgisi ile ciddi bir darbe alan Hoybun Örgütü'nün, dışarıdan destek bulmasının da zorlaştığı bu dönemde kendini toparlayıp tekrar bir askeri mücadeleye girişmesi imkânsız hale gelmiştir. Her ne kadar yaptığı yayınlarla dışarda sesini duyurma çabalarını sürdürse de tüm dünyanın dikkatinin gittikçe belirginleşen statükocu-revizyonist kutuplaşmasına odaklandığı bir ortamda Hoybun'un çabaları etki yaratmaktan çok uzak kalmıştır.

II. Dünya Savaşı'nın patlak vermesi ile birlikte Hoybun'un faaliyetlerini devam ettirmesi iyice zora girmiştir. Örgüt, savaş nedeniyle -Jwaideh'e (2003: 278) göre Fransızların da talebi ile- çalışmalarına ara vermiştir (Dersimi 1992: 254; Alakom 1998: 115). Bu dönemde Hoybun adına faaliyetler kişisel çabalar düzeyinde kalmıştır. Bazı isimler Hoybun adına uluslararası konferanslara mektuplar göndermişlerdir. 1939-1946 y1lları arasında örgütün siyasi temsilciliğini yapan Cemilpaşazade Ekrem de bu dönemde faaliyetlerini 
sürdürmüştür. (Kurubaş 1997: 186). Savaş sona erdiğinde, Hoybun uzun süredir ara verdiği ilişkileri canlandırma girişimlerinde bulunmuştur. Bu dönemde örgüt isim değiştirmiştir. 1946 yılında, Civata Azadi ü Yekitiya Kurdistane (Kürdistan Özgürlügü ve Birliği Örgütü) adını almıştır. Daha sonra Qadi Mıhammed'in başkanı olduğu Kürdistan Demokrat Partisi'nin bir şubesi durumuna gelmiştir (Cegerxwin 2003: 281). Ekrem Cemilpaşazade (1991: 77), 1946'da Mehabet Kürt Cumhuriyeti'nin kurulmasıyla, diğer Kürt örgütleri gibi Hoybun'un da kendini feshederek, bu cumhuriyete katıldığını kaydetmektedir.

Gerek örgüt içi görüş ayrılıkları, gerekse uluslararası ortamda yaşanan değişim Hoybun Örgütü'nü sona götüren süreci hazırlamıştır. Örgütün bir başka zayıf yönü kendi iddiasının aksine bütün Kürtleri temsil edebilecek bir yapıda olmamasıdır. Sürgündeki Kürtlerden oluşan küçük topluluk, kendini Kürt halkına mal edememiştir (Kurubaş 1997: 176). Bu da bir örgütün yaşayıp, büyümek için temel gereksinimi olan halk desteğini, Hoybun'un yeterince sağlayamadığ hareketinde önemli değişimlerin altına adını yazarak, kuruluşunun üstünden yaklaşık 20 sene geçtikten sonra tamamıyla dağılmıştır.

\section{SONUÇ: Hoybun'un Mirası}

Hoybun Örgütü, kendi döneminde çok ciddi kazanımlar elde edemese de, pek çok yönü ve yaklaşımları ile Kürt hareketine yeni bir soluk getirmiştir ve kendinden sonraki örgütler için önemli bir birikim bırakmıştır. Hoybun'dan önceki örgütlenmelere baktığımızda, bu şekilde askeri ve idari yapılanma içine giren bir örgüt olmadığı görülmektedir. Ama belki de Hoybun'un en önemli özelliği, bağımsız bir Kürt devletinin dünya kamuoyunun dikkatini çekmeden, yabancı devletlerin desteğini almadan kurulamayacağını görmüş ve bunu uygulamalarına yansıtmış olmasıdır. Nitekim Nikitin (1991: 337), Kürt milliyetçi hareketinin üç evre geçirdiğini ve Hoybun'un kuruluşuyla yeni bir evreye girildiğini söyler. Birinci evre serkeşlik, sosyal kargaşa ve ayrıcalıklarını kıskançca korumak isteyen feodallerin ayaklanması dönemidir. İkinci evre, Jön Türkler hareketiyle birlikte Kürtlerin ulusal özelliklerini tanıyacak bir konum elde etme yönünde girişimlerin yapıldığı dönemdir. Üçüncü evre ise, Birinci Dünya Savaşı sonrası başlayan Kürt sorununun uluslararası boyut kazandığı dönemdir. Kürt ulusal hareketi 1927 'de Hoybun'la beraber üçüncü evreye girmiştir.

Örgüt daha başında askeri bir mücadele planlarken, öbür tarafta bu mücadeleyi etkinleştirmek için gerekli olan propaganda faaliyetleri için düzenlemeler yapmıştır. Diğer örgütlerle kıyaslandığında Hoybun'un diplomatik ilişkiler geliştirmekte önemli bir adım attığını görülmektedir. Öncellikle, örgüt sadece içeride verilen askeri mücadelenin bağımsızlık için yeterli olmadığını çok açık şekilde ortaya koymuştur. Uluslararası kamuoyunda seslerini duyurmak, dönemin büyük güçlerinin siyasi desteğini kazanmak hayati görülmüştür. $\mathrm{Bu}$ amaçla Ermenilerle kurulan ittifak çarpıcıdır. Akabinde uluslararası konferanslara gönderilen temsilciler, ikili temaslar, elçiliklere yazılan mektuplar, bir Kürt örgütünün o zamana kadar başvurmadığı yoğunlukta diplomatik çabalardır. Bunun yanı sıra, Türkçe, İngilizce, Fransızca ve Arapça yayınlar, dünyanın çeşitli merkezlerinde kurulan temsilcilikler ve buralarda yürütülen faaliyetler, Hoybun'un sadece hükümetler düzeyinde değil halklar düzeyinde de sesini duyurma çabasında olduğunu göstermektedir. 
Hoybun'un Ağrı İsyanı'nındaki rolü ve stratejisi de örgütü ayrılacıklı bir yere koymaktadır. $\mathrm{Bu}$ isyan sürecinde düzenli bir askeri yapılanma yaratılmaya çalışılmış, isyanın başına bir komutan atanmış, bizzat örgüt merkezinde stratejiler geliştirilmiş ve bu stratejiler askeri kanat tarafından uygulanmaya konmuştur. Oysa önceki isyanlara baktığımızda, bu isyanların aşiret reislerince ya da şeyhler tarafından yürütüldüğünü, çoğu zaman kontrolsüz geliştiğini ve genellikle bağımsızlık idealinden çok tepkisel yönlerinin önplanda olduğunu görürüz. Ağrı İsyan'1 sırasında örgüt, hükümet gibi hareket ederek askeri ve idari atamalar yapmıştır. Burada bir devletin tüm sembolleri görülmektedir. İhsan Nuri, anılarında, Ağrı Marşı'nın okunduğunu söyler ve ele geçen bölgelere Kürt Bayrağı dikildiğini, askerlerin üniformalarında Hoybun amblemi bulunduğundan bahsetmektedir. O zamana kadar ki Kürt örgütlenmelerinin hiç biri bu şekilde bir yapılanma içine gitmemişlerdir. Hoybun, o zamana kadar zihinlerde olan bağımsız devleti, askeri, idari yapılarıyla, bayrak ve marşı ile somut hale dönüştürme gayesi gütmüştür. Hoybun her ne kadar ortaya koyduğu hedeflerin pek çoğunu gerçekleştirmekte başarısız olmuş ve etkisi sınırlı kalmış olsa da gerek söylemsel, gerekse yöntem olarak getirdiği yeniliklerle Kürt hareketin içinde kendinden sonraki örgütlenmeleri etkilemiş ve Kürt sorununun uluslararası platforma taşınmasında öncü bir rol oynamıştır.

\section{KAYNAKLAR}

Alakom, R. (1998). Hoybun Örgütü ve Ağrı Ayaklanması. İstanbul: Avesta Yayınları,

Aytepe, O. (1998a). "Hoybun Cemiyeti'nin Amerika Faaliyetleri”.Tarih ve Toplum Dergisi, $30: 176,55-59$

Aytepe, O. (1998b). "Yeni Belgeler Isı̆̆ında Hoybun Cemiyeti”.Toplumsal Tarih Dergisi. 10:58, 50-55.

Başbakanlık Cumhuriyet Arşivi, 030.10.115/796/20.

Başbakanlık Cumhuriyet Arşivi, 030.10.115/803/3).

Başbakanlık Cumhuriyet Arşivi, 030.10.115/803/5.

Bayrak, M. (der.) (1994). Açık-Gizli/ Resmi-Gayriresmi Kürdoloji Belgeleri, Ankara: Öz-Ge Yayınları.

Bedirhan, P. S. (1994). Kürt Davası ve Hoybun. D. Zirek (çev.). İstanbul: Med Yayınları.

Burkay, K. (1978). Kürdistan’ın Sömürgeleştirilmesi ve Kürt Ulusal Hareketleri. İstanbul: Özgürlük Yolu Yayınları.

Cegerxwin (2003). Hayat Hikayem. İstanbul: Evrensel Basım Yayın.

Cöhçe, Salim (2000). "Büyük Ermenistan'1 Kurma Projesinde Kürtlere Biçilen Rol”. I. Milletlerarası Doğu ve Güneydoğu Anadolu'da Güvenlik Sempozyumu. 27-29 Mart. Elazığ. 511-525.

Dersimi, M. N. (1992). Kürdistan Tarihinde Dersim. 4. B. Diyarbakır: Dilan Yayınları.

Ekrem Cemil Paşa (1989). Muhtasar Hayatım. 2. B. Brüksel: Brüksel Kürt Enstitüsü Yayınları. 
Ferheng Kürtçe Online Sözlük, http://ferheng.org/tr/

Göktaş, H. (1991). Kürtler I İsyan-Tenkil. 3. B. İstanbul: Alan Yayıncılık.

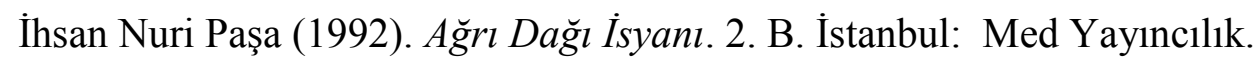

Jwaideh, W. (2003). Kürt Milliyetçiliğinin Tarihi Kökenleri ve Gelişimi, İ. Çekem, A.Duman (çev). İstanbul: İletişim Yayınları.

Kahraman A. (2004). Kürt İsyanları (Tedip ve Tenkil). İstanbul: Evrensel Basın ve Yayım

Kalafat, M. (1992). Şark Meselesi Işı̆̆ııda Şeyh Sait Olayı, Karakteri, Dönemindeki İç ve Dış Olaylar. İstanbul: Boğaziçi Yayınları.

Kalman, M. (1997). Belge Tanık ve Yasayanlarıyla Ağrı Direnişi (1926-1930). İstanbul: Peri Yayınları.

Karaca, E. (2003). Ăgrı Eteklerinde İsyan: Bir Kürt Ayaklanmasının Anatomisi. İstanbul: Karakutu Yayınları.

Kaya, Y. (2001). Fehmi Bilal (Liceli Fehmi). Özgür Politika, 20 Mart, <http: //www.biyografi.net/kisiayrinti.asp?kisiid=2764>

Kocaş, M.S. (1990). Tarihte Ermeniler ve Türk Ermeni İlişkileri. İstanbul: Kastaş Yayınları.

Kurubaş, E. (1997). Başlangıçtan 1960'a Değin: Kürt Sorununun Uluslararası Boyutu. Ankara: Ümit Yayıncılık.

Malmisanij (2004). Diyarbakırlı Cemilpaşazadeler ve Kürt Milliyetçiliği. İstanbul: Avesta Basin Yayın.

Nikitin, B. (1991). Kürtler, Sosyolojik ve Tarihi Ínceleme, H.Demirhan (çev.) Cilt I-II. 3. B. İstanbul: Deng Yayınları.

Oran, B. (2003). Dönemin Bilançosu 1919-1923. Türk Dış Politikası, Kurtuluş Savaşından Bugüne Olgular, Belgeler, Yorumlar. B Oran (der.). Cilt I, 7. B, İstanbul: İletişim Yayınları.

Öznur, H. (2003). Cahşların Savaşı. Ankara: Atınküre Yayınları.

Sarınay, Y. (1998). “Hoybun Cemiyeti ve Türkiye’ye Karşı Faaliyetleri”. Ataturk Arastırma Merkezi Dergisi. XIV:40. http://www.atam.gov.tr/dergi/sayi-40/hoybun-cemiyeti-veturkiyeye-karsi-faaliyetleri. erişim tarihi: 10 Temmuz 2015.

Sasuni, G. (1986). Kürt Ulusal Hareketleri ve 15.yy dan Günümüze Ermeni-Kürt İlişkileri. Stockholm : Orfeus

Şadillili, V. (1980). Türkiye'de Kürtçülük Hareketleri ve İsyanlar. Cilt I. Ankara: Kon Yayınları.

Şimşir, B. (1975) İngiliz Belgeleriyle Türkiye'de Kürt Sorunu, 1924-38. Ankara: Dışişleri Bakanlığı Basımevi. 
Uzgel, İ.. (2003). İngiltere'nin Kürt Politikası. Türk Dış Politikası, Kurtuluş Savaşından Bugüne Olgular, Belgeler, Yorumlar. B Oran (der.). Cilt I, 7. B, İstanbul: İletişim Yayınları

Yavuz, S. (Ed.) (2005). Taşnak-Hoybun, İstanbul: İleri Yayınları.

Yıldız, Z. (1992). Kürt Gerçeği: Olaylar, Oyunlar, Çözümler. İstanbul: Yeni Asya Yayınları. 